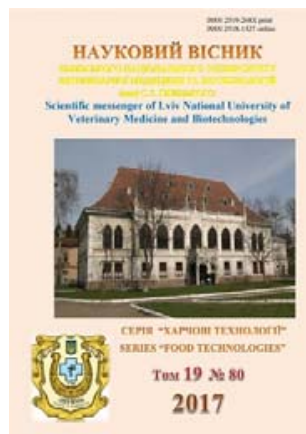

Науковий вісник Львівського національного університету ветеринарної медицини та біотехнологій імені С.3. Гжицького

Scientific Messenger of Lviv National University of Veterinary Medicine and Biotechnologies

doi:10.15421/nvlvet8025

ISSN 2519-268X print

ISSN 2518-1327 online

$\underline{\text { http://nvlvet.com.ua/ }}$

УДК 639.382:637.03

\title{
Встановлення режимів термічної обробки ікри прісноводної риби для підвищення ії мікробіологічної безпеки
}

\author{
А.А. Менчинська ${ }^{1}$, О.В. Яблонська ${ }^{1}$, Т.К. Лебська ${ }^{2}$ \\ menchynska@ukr.net \\ ${ }^{1}$ Національний університет біоресурсів і природокористування України, \\ вул. Героїв Оборони, 11, м. Київ, 03041, Украӥна; \\ ${ }^{2}$ Київський національний торговельно-економічний університет, \\ вул. Кіото, 19, м. Київ, 02156, Україна
}

\begin{abstract}
Рибна ікра є одним з найцінніших продуктів харчування та сприятливим середовищем для існування та розмноження мікроорганізмів. Одним із найбільш відомих методів збереження якості ікри є пастеризування. На даний час використовують різні режими пастеризування як за температурою, так $і$ за часом. Температура може коливатися від $63{ }^{\circ} \mathrm{C}$ до вище $100{ }^{\circ} \mathrm{C}$. За рахунок вмісту білку, поліненасичених жирних кислот ікра дуже чутлива до температурного впливу. Успішна розробка якісних та безпечних харчових продуктів на основі ікри прісноводної риби можлива за умови удосконалення і уточнення режимів термічного оброблення ікри. Метою роботи є обтрунтування режимів термічного оброблення ікри прісноводної риби на основі мікробіологічних показників. В якості сировини для дослідження використовували ікру товстолобика (Hурорhthalmichthys) i коропа (Сурrinus сагріо). 3 метою визначення оптимальної температури теплового оброблення ікру прісноводної риби піддавали термічному обробленню за температури $60^{\circ} \mathrm{C}, 65^{\circ} \mathrm{C}, 70^{\circ} \mathrm{C}, 75^{\circ} \mathrm{C}, 80^{\circ} \mathrm{C}$ протягом 60 хвилин. Оптимальною температурою, що забезпечувала повне знищення умовно-патогенних мікроорганізмів і допустиму кількість залишкової мікрофлори (МАФАнМ) визначено $70-75^{\circ} \mathrm{C}$. Тривалість проиесу термічного оброблення встановлювали на основі оцінки динаміки зміни кількості МАФАнМ за температури $70^{\circ} \mathrm{C}$ протягом 30, 45, 60, 75, 90 хвилин. Раціональною тривалість теплового оброблення є 75 хвилин, щзо забезпечує знищення вегетативних форм мікроорганізмів, а кількість залишкової мікрофлори знаходиться в межах допустимої норми.

Ключові слова: ікра, товстолобик, короп, термічне оброблення, емульсійний продукт, залишкова мікрофлора, оптимальні параметри, температура, тривалість, мікробіологічні показники.
\end{abstract}

\section{Установление режимов термической обработки икры пресноводной рыбы для повышения ее микробиологической безопасности}

\author{
А.А. Менчинская ${ }^{1}$, О.В. Яблонская ${ }^{1}$, Т.К. Лебская ${ }^{2}$ \\ menchynska@ukr.net \\ ${ }^{1}$ Национальный университет биоресурсов и природопользования Украины, \\ ул. Героев Обороны, 11, г. Киев, 03041, Украина; \\ ${ }^{2}$ Киевський национальный торгово-экономический университет, \\ ул. Киото, 19, г. Киев, 02156, Украина
}

\begin{abstract}
Рыбная икра является одним из самых иенных продуктов питания и благоприятной средой для существования и размножения микроорганизмов. Одним из самых известных методов сохранения качества икры является пастеризаџия. В настоящее время используют различные режимы пастеризации как по температуре, так и по времени. Температура может колебаться от $63^{\circ} \mathrm{C}$ до выше $100^{\circ} \mathrm{C}$. За счет содержания белка, полиненасыщенных жирных кислот икра очень чувствительна к температурному воздействию. Успешная разработка качественных и безопасных пищевых продуктов на основе
\end{abstract}

Citation:

Menchynska, A.A., Yablonska, O.V., Lebska, T.K. (2017). Determination of heat treatment regime of fresh-water fish roe for the increasing its microbiological safety. Scientific Messenger LNUVMB, 19(80), 119-122. 
икры пресноводной рыбы возможна при условии совершенствования и уточнения режимов термической обработки икры. Целью работы является обоснование режимов термической обработки икры пресноводной рыбы на основе микробиологических показателей. В качестве сырья для исследования использовали икру толстолобика (Нурорһthаlтісһthys) и карпа (Сургіпus сагріо). С иелью определения оптимальной температуры тепловой обработки икру пресноводной рыбы подвергали термической обработке при температуре $60^{\circ} \mathrm{C}, 65^{\circ} \mathrm{C}, 70^{\circ} \mathrm{C}, 75^{\circ} \mathrm{C}, 80^{\circ} \mathrm{C}$ в течение 60 минут. Оптимальной температурой, которая обеспечивала полное уничтожение условно-патогенных микроорганизмов и допустимое количество остаточной микрофлоры (МАФАнМ) определено 70-75 ${ }^{\circ}$ С. Продолжительность прочесса термической обработки устанавливали на основе оценки динамики изменения количества МАФАнМ при температуре 70 ${ }^{\circ} \mathrm{C}$ течение 30 , 45, 60, 75, 90 минут. Рациональной продолжительность тепловой обработки является 75 минут, что обеспечивает уничтожение вегетативных форм микроорганизмов, а количество остаточной микрофлоры находится в пределах допустимой нормыл.

Ключевые слова: икра, толстолобик, карп, термическая обработка, эмульсионный продукт, остаточная микрофлора, оптимальные параметры, температура, продолжительность, микробиологические показатели.

\title{
Determination of heat treatment regime of fresh-water fish roe for the increasing its microbiological safety
}

\author{
A.A. Menchynska ${ }^{1}$, O.V. Yablonska ${ }^{1}$, T.K. Lebska ${ }^{2}$ \\ menchynska@ukr.net \\ ${ }^{I}$ National University of Life and Environmental Sciences of Ukraine, \\ st. Heroes of Defense, 11, Kyiv, 03041, Ukraine, \\ ${ }^{2}$ Kiev National University of Trade and Economics, \\ st. Kyoto, 19, Kyiv, 02156, Ukraine
}

Fish roe is one the most valuable food products; however it is very suitable environment for existence and reproduction of microorganisms. One of the best known methods for keeping fish roe quality is pasteurization. Currently, different pasteurization regimes are used both at temperature and time. The temperature can vary from 63 to above $100{ }^{\circ} \mathrm{C}$. Because of the protein content in polyunsaturated fatty acids, the roe is very sensitive to temperature. Successful development of high-quality and safe food products based on freshwater fish roe is possible when it is provided with improvement and updating of heat treatment regimes. The aim of the work is to substantiate the regimes of heat treatment of freshwater fish roe on the base of its microbiological indicators. As raw material for the study, ich roe (Hypophthalmichthys) and carp roe (Cyprinus carpio) were used. In order to determine the optimum temperature of heat treatment the freshwater fish roe were subjected to heat treatment at a temperature of $60^{\circ} \mathrm{C}, 65^{\circ} \mathrm{C}, 70^{\circ} \mathrm{C}$, $75^{\circ} \mathrm{C}, 80^{\circ} \mathrm{C}$ for 60 minutes. The optimum temperature ensuring complete destruction of commensals and allow the permissible amount of residual microflora (MAFAnM) is determined at $70-75^{\circ} \mathrm{C}$. The duration of the heat treatment process was determined on the base of evaluation of dynamics in amount changes of MAFAnM at a temperature of $70{ }^{\circ} \mathrm{C}$ for 30, 45, 60, 75, 90 minutes. The rational duration of heat treatment is 75 minutes, which ensures the destruction of vegetative forms of microorganisms, and the amount of residual microflora is within the permissible norm.

Key words: roe, ich, carp, heat treatment, emulsion product, residual microflora, optimal parameters, temperature, duration, microbiological indices.

\section{Вступ}

Рибна ікра є одним із найцінніших продуктів харчування, завдяки високому вмісту повноцінних білків, біологічно ефективних жирів, вітамінів, макро- та мікроелементів (Baydalinova and Yarzhombek, 2012). В останні роки осетрова та лососева ікра являється делікатесною продукцією не доступною для широких верств населення. При цьому обсяги виробництва прісноводної аквакультури зростають (Holembovska and Lebska, 2014). Актуальним стає створення біологічно-повноцінної продукції на основі ікри прісноводної риби. За зовнішнім виглядом ікра прісноводних риб характеризується темним кольором, ікринками маленького розміру і не дуже користується попитом у населення в натуральному вигляді. Тому важливим завданням у використані ікри прісноводних риб є створення харчового продукту привабливого за зовнішнім виглядом та поліпшеними смаковими властивостями, показниками біологічної цінності, ефективності та безпеки. Найбільшу загрозу в харчовій технології становлять мікроорганізми - збудники псування сировини і готової продукції, токсичні продук- ти їх життєдіяльності, що спричиняють захворювання людини.

Ікра прісноводної риби є сприятливим середовище для існування та розмноження мікроорганізмів. Мікрофлора ікри може бути природньою (психрофільні мікроорганізми) та набутою в процесі переробки (стафілококи, бактерії групи кишкової палички, спори бактерій, гриби, дріжджі). Набута мікрофлора за короткий час робить продукцію непридатною або навіть шкідливою для споживання (Altug and Bayrak, 2003). Тому при виробництві ікри необхідно суворо дотримуватись санітарно-гігієнічних вимог і застосовувати методи обробки, які забезпечують пригнічення життєдіяльності мікроорганізмів, інактивацію ферментів, не погіршуючи органолептичні показники.

Одним із найбільш відомих методів збереження якості ікри є пастеризування. Даний метод заснований на частковій термічній деструкції мікроорганізмів, які представляють потенційну загрозу для псування продуктів. Нормальна життєдіяльність мікроорганізмів проходить у певних температурних межах, від яких залежить швидкість їх розмноження, інтенсивність перебігу процесів обміну речовин у клітинах. Високі 
температури є згубними для мікроорганізмів, іннактивують ферменти, однак викликають руйнування поліненасичених жирних кислот, денатурацію білків (Al-Holy and Quinde, 2004; Peretruhina and Peretruhina, 2005).

Дослідженню параметрів процесу термічного оброблення рибної ікри присвячені праці багатьох закордонних вчених (Altug and Bayrak, 2003; Al-Holy and Quinde, 2004; Jelodar and Safari, 2006; Khakbaz Heshmati et al., 2014). На основі їхніх досліджень встановлено, що рибна ікра завдяки вмісту білку, поліненасичених жирних кислот дуже чутлива до впливу високих температур (Khakbaz Heshmati et al., 2014). Термічне оброблення до $60{ }^{\circ} \mathrm{C}$ сприятливе для росту і розмноження мікроорганізмів, тому не відбувається зменшення мікробного обсіменіння. Теплове оброблення за температури вище $80{ }^{\circ} \mathrm{C}$ повністю знищує вегетативні мікроорганізми, але зумовлює не зворотну денатурацію білку, що негативно впливає на органолептичні та функціонально-технологічні показники ікри, сировина стає не придатною для виготовлення емульсійних продуктів (Jelodar and Safari, 2006). Тому, успішне розроблення якісних та безпечних харчових продуктів на основі ікри прісноводної риби можливе за умови удосконалення і уточнення режимів термічного оброблення ікри.

Мета роботи - обгрунтувати режими термічного оброблення ікри прісноводної риби на основі мікробіологічних показників

\section{Матеріал і методи досліджень}

В якості сировини для дослідження використовували ікру товстолобика (Hypophthalmichthys) і коропа (Cyprinus carpio) IV стадії зрілості, що зберігалась в замороженому вигляді протягом 1 місяця.

Ікру прісноводної риби фасовану в скляні банки місткістю 112 г піддавали термічному обробленню за температури $60{ }^{\circ} \mathrm{C}, 65^{\circ} \mathrm{C}, 70^{\circ} \mathrm{C}, 75^{\circ} \mathrm{C}, 80{ }^{\circ} \mathrm{C}$ протягом 60 хвилин. Тривалість процесу термічного оброблення встановлювали на основі оцінки динаміки зміни кількості мезофільних аеробних та факультативноанаеробних мікроорганізмів (МАФАнМ) при термічному обробленні за температури $70{ }^{\circ} \mathrm{C}$ протягом 30 , 45, 60, 75, 90 хвилин.

Кількість МАФАнМ визначали згідно з ГОСТ 10444.15-94; бактерій групи кишкової палички (БГКП) згідно з ГОСТ 30518-93; золотистого стафілококу згідно з ГОСТ 10444.2-94; патогенних мікроорганізмів, в т.ч. роду Сальмонела згідно з ДСТУ ISO 11290-1, ДСТУ ISO 11290-2, ДСТУ EN 12824.

\section{Результати та їх обговорення}

Важливим критерієм, що визначає випуск доброякісних, безпечних в епідеміологічному відношенні і стійких при зберіганні продуктів харчування $є$ мікробіологічні показники сировини. Мікробіологічні показники ікри наведені в таблиці 1.

Мікробіологічні показники ікри

\begin{tabular}{|c|c|c|c|}
\hline Найменування показників & Ікра коропа & Ікра товстолобика & Допустимий рівень \\
\hline МАФАнМ, КУО в 1 г & $6,4 \times 10^{4}$ & $7,2 \times 10^{4}$ & $1 \times 10^{5}$ \\
\hline БГКП (коліформи), в 0,001г & Не виявлено & Не виявлено & Не допускається \\
\hline Золотистий стафілокок, у 0,01 г & Не виявлено & Не виявлено & Не допускається \\
\hline $\begin{array}{c}\text { Патогенні мікроорганізми, в т.ч. роду Са- } \\
\text { льмонела, у 25 г }\end{array}$ & Не виявлено & Не виявлено & Не допускається \\
\hline
\end{tabular}

Резельтати таблиці 3.14 свідчать, що в ікрі коропа кількість МАФАнМ складає $6,4 \times 10^{4}$ КУО в 1 г, а в ікрі товстолобика $7,2 \times 10^{4}$ кількість КУО в 1 г при допустимому рівні $1 \times 10^{5}$ КУО в 1 г, бактерії групи кишкової палички, золотистий стафілокок та патогенні мікроорганізми, в т.ч. Сальмонела не виявлені. Отже, мікробіологічні показники ікри коропа та товстолобика не перевищують межі встановлених допустимих норм (Instruktsii ро sanitarnomikrobiologicheskomu kontrolyu, 1991).
Так як рибна ікра є сприятливим середовищем для розмноження мікроорганізмів, наявна мікрофлора за короткий час зробить іiї не придатною для виробництва і споживання. Тому необхідно застосовувати термічне оброблення, що, в залежності від режиму температури та тривалості, сприяє підвищенню безпеки сировини та харчових продуктів. Результати досліджень мікробіологічних показників ікри товстолобика після термічного оброблення підтверджують ці дані (табл. 2).

Табличя 2

Мікробіологічні показники ікри після термічного оброблення

\begin{tabular}{|c|c|c|c|c|c|c|c|}
\hline \multirow{2}{*}{\multicolumn{2}{|c|}{ Назва показників }} & \multicolumn{5}{|c|}{ Температура термічної обробки, ${ }^{\circ} \mathrm{C}$} & \multirow{2}{*}{$\begin{array}{l}\text { Допустимий } \\
\text { рівень }\end{array}$} \\
\hline & & 60 & 65 & 70 & 75 & 80 & \\
\hline \multirow{2}{*}{$\begin{array}{c}\text { МАФАнМ, } \\
\text { КУО в } 1 \text { г }\end{array}$} & ікра товстолобика & $1,6 \times 10^{4}$ & $7,3 \times 10^{3}$ & $4,8 \times 10^{3}$ & $1 \times 10^{3}$ & $7 \times 10^{2}$ & \multirow[t]{2}{*}{ Не більше $5 \times 10^{3}$} \\
\hline & ікра коропа & $1,2 \times 10^{4}$ & $6,6 \times 10^{3}$ & $3,4 \times 10^{3}$ & $9 \times 10^{2}$ & $5 \times 10^{2}$ & \\
\hline \multicolumn{2}{|c|}{ Плісеневі гриби, КУО в 0,1 г } & \multicolumn{5}{|c|}{ Не виявлено } & Не допускаються \\
\hline \multicolumn{2}{|c|}{ Дріжджі КУО в 0,1 г } & \multicolumn{5}{|c|}{ Не виявлено } & Не допускаються \\
\hline \multicolumn{2}{|c|}{ БГКП (коліформи), в 1г } & \multicolumn{5}{|c|}{ Не виявлено } & Не допускаються \\
\hline \multicolumn{2}{|c|}{ Золотистий стафілокок, в 1 г } & \multicolumn{5}{|c|}{ Не виявлено } & Не допускаються \\
\hline \multicolumn{2}{|c|}{ Сульфітредукуючі клостридії,в 1 г } & \multicolumn{5}{|c|}{ Не виявлено } & Не допускаються \\
\hline \multicolumn{2}{|c|}{$\begin{array}{l}\text { Патогенні мікроорганізми, в т.ч. роду } \\
\text { Сальмонела, в } 25 \text { г }\end{array}$} & \multicolumn{5}{|c|}{ Не виявлено } & Не допускаються \\
\hline
\end{tabular}


Результати таблиці 2, показують, що в діапазоні температур від $60{ }^{\circ} \mathrm{C}$ до $65^{\circ} \mathrm{C}$ кількість МАФАнМ складає від $1,6 \times 10^{4}$ до $7,3 \times 10^{3}$, що перевищує допустимій їх рівень. В результаті термічної обробки за температури $75-80{ }^{\circ} \mathrm{C}$ візуально було відмічено затвердіння ікринок, внаслідок денатураційних змін білка, що призводить до погіршення органолептичних та функціонально-технологічних показників ікри (Jelodar and Safari, 2006). Тому даний температурний режим $є$ недоцільним. Оптимальною температурою, що забезпечувала допустиму кількість залишкової мікрофлори (МАФАнМ) визначено 70-75 ${ }^{\circ} \mathrm{C}$. Плісневі гриби, дріжджі, колі форми, золотистий стафілокок, сульфітредукуючі клострідії та патогенні мікроорганізми не виявлено за всіх температурних режимів.

Тривалість процесу термічного оброблення також суттєво впливає на якість та безпеку ікри (рис. 1).

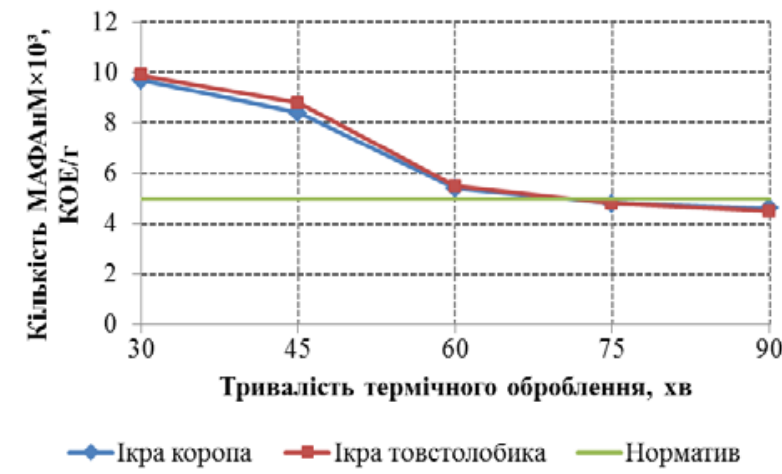

Рис. 1. Встановлення тривалості термічного оброблення ікри прісноводної риби

Проведені дослідження показали, що за термічного оброблення протягом 30 і 45 хвилин спостерігається не значна загибель мікроорганізмів. Різке зменшення мікробного обсіменіння визначено нами після 60 хвилин термічного оброблення. Раціональною тривалість теплового оброблення $є 75$ хвилин, що забезпечує знищення вегетативних форм мікроорганізмів, а кількість залишкової мікрофлори знаходиться в межах допустимої норми. Збільшення тривалості термічного оброблення практично не впливає на кількість МАФАнМ, тому є не доцільною, що узгоджується з даними літератури (Chernyshova, 2015).

\section{Висновки}

1. Визначення режимів термічного оброблення ікри прісноводних риб $є$ актуальною проблемою, вирішення якої буде сприяти підвищенню безпеки сировини, харчового продукту та забезпеченню якості.
2. Оптимальною температурою, що забезпечує безпечність ікри прісноводних риб за показником кількості залишкової мікрофлори (МАФАнМ) є температура у діапазоні $70-75^{\circ} \mathrm{C}$.

3. Раціональною тривалість теплового оброблення $є 75$ хвилин, що забезпечує кількість залишкової мікрофлори в межах допустимої норми.

\section{Бібліографічні посилання}

Baydalinova, L.S., Yarzhombek, A.A. (2012). Biohimiya syirya vodnogo proishozhdeniya. Baydalinova. M.: Morkniga (in Russian).

Holembovska, N.V., Lebska, T.K. (2014). Rozvytok rynku rybnykh produktiv $\mathrm{V}$ Ukraini. Prodovolcha industriia APK. 4, 4-8 (in Ukrainian).

Altug, G., Bayrak, Y. (2003). Microbiological analysis of caviar from Russia and Iran. Food Microbiology. 20, 83-86.

Peretruhina, A.T., Peretruhina, I.V. (2005). Mikrobiologiya syirya i produktov vodnogo proishozhdeniya. SPb.: GIORD (in Russian).

Al-Holy, M., Quinde, Z. (2004). Thermal inactivation of Listeria innocua in salmon (Oncorhynchus keta) caviar using conventional glass and novel aluminum thermaldeath-time tubes. Journal of Food Protection. 67(2), 383-386.

Khakbaz Heshmati, M., Shahedi, M., Hamdami, N. (2014). Mathematical Modeling of Heat Transfer and Sterilizing Value Evaluation during Caviar Pasteurization. Agri. Sci. Technol. 16, 827-839.

Jelodar, A.S., Safari, R.J. (2006). Microbial and Chemical Quality Evaluation of Caviar in Iranian Processing Plants in Line with the European Community Code. Applied Ichthyology. 22, 411-415.

Instruktsii po sanitarno-mikrobiologicheskomu kontrolyu proizvodstva pischevoy produktsii iz ryibyi i morskih bespozvonochnyih: SanPiN 5319-91. L.: Giproryibflot, 1991 (in Russian).

Chernyshova, O.V. (2015). Obosnovanie i razrabotka tekhnologii farshevyh produktov iz karasya serebryanogo (Sarassius auratus gibelio): dis. na soiskanie uch. stepeni kand. tekhn. nauk: spec. 05.18.04 «Tekhnologiya myasnyh, molochnyh i rybnyh produktov i holodil'nyh proizvodstv». Astrahan' (in Russian). 